\title{
The association between smoking, beverage consumption, diet and bladder cancer: a systematic literature review
}

Citation for published version (APA):

Zeegers, M. P. A., Kellen, E., Buntinx, F. J. V. M., \& van den Brandt, P. A. (2004). The association between smoking, beverage consumption, diet and bladder cancer: a systematic literature review. World Journal of Urology, 21(6), 392-401. https://doi.org/10.1007/s00345-003-0382-8

Document status and date:

Published: 01/01/2004

DOI:

10.1007/s00345-003-0382-8

Document Version:

Publisher's PDF, also known as Version of record

Please check the document version of this publication:

- A submitted manuscript is the version of the article upon submission and before peer-review. There can be important differences between the submitted version and the official published version of record.

People interested in the research are advised to contact the author for the final version of the publication, or visit the DOI to the publisher's website.

- The final author version and the galley proof are versions of the publication after peer review.

- The final published version features the final layout of the paper including the volume, issue and page numbers.

Link to publication

\footnotetext{
General rights rights.

- You may freely distribute the URL identifying the publication in the public portal. please follow below link for the End User Agreement:

www.umlib.nl/taverne-license

Take down policy

If you believe that this document breaches copyright please contact us at:

repository@maastrichtuniversity.nl

providing details and we will investigate your claim.
}

Copyright and moral rights for the publications made accessible in the public portal are retained by the authors and/or other copyright owners and it is a condition of accessing publications that users recognise and abide by the legal requirements associated with these

- Users may download and print one copy of any publication from the public portal for the purpose of private study or research.

- You may not further distribute the material or use it for any profit-making activity or commercial gain

If the publication is distributed under the terms of Article 25fa of the Dutch Copyright Act, indicated by the "Taverne" license above, 


\section{The association between smoking, beverage consumption, diet and bladder cancer: a systematic literature review}

Received: 3 November 2003/ Accepted: 3 November 2003/Published online: 17 December 2003

(C) Springer-Verlag 2003

\begin{abstract}
In this paper the association between smoking history, beverage consumption, diet and bladder cancer incidence is systematically reviewed. A rating system has been used to summarise the level of scientific evidence (i.e. convincing, probable, possible, and no evidence) and the level of association (i.e. substantially increased, $(\mathrm{RR} \geq 2.5)$, moderately increased $(1.5 \leq \mathrm{RR}<2.5)$, slightly increased $(1.2 \leq \mathrm{RR}<1.5)$, no association $(0.8 \leq \mathrm{RR}<1.2)$, slightly decreased $(0.7 \leq \mathrm{RR}<0.8)$, moderately decreased $(0.4 \leq \mathrm{RR}<0.7)$, and substantially decreased $(\mathrm{RR}<0.4))$. There is convincing evidence that cigarette smoking status, frequency and duration substantially increase the risk of bladder cancer. However, the evidence is not clear for other forms of smoking. A small increased risk for cigar, pipe, and environmental smoking is only possible. There is possible evidence that total fluid intake is not associated with bladder cancer. Although there is convincing evidence for a positive association between alcohol consumption and bladder cancer risk in men, the risk is small and not clinically relevant. Coffee and tea consumption are probably not associated with bladder cancer. The authors conclude that total fruit consumption is probably associated with a small decrease in risk. There is probably no association between total vegetable intake, vitamin $\mathrm{A}$ intake, vitamin $\mathrm{C}$ intake and bladder cancer and a possibly moderate inverse association with vitamin $\mathrm{E}$ intake. Folate is possibly not associated with bladder cancer. There probably is a moderate inverse association between selenium intake and bladder cancer risk.
\end{abstract}

M. P. A. Zeegers $(\bowtie) \cdot$ F. Buntinx $\cdot$ P. A. van den Brandt Department of Epidemiology, Maastricht University, P.O. Box 616, 6200 MD Maastricht, The Netherlands E-mail: mpa.zeegers@epid.unimaas.nl

M. P. A. Zeegers · E. Kellen · F. Buntinx Comprehensive Cancer Institute Limberg, Department of General Practice, University of Leuven, Kapucijnenvoer 33, blok J, 3000 Leuven, Belgium
Keywords Smoking $\cdot$ Nutrition $\cdot$ Diet $\cdot$ Bladder neoplasms $\cdot$ Review $\cdot$ Epidemiology

Bladder cancer is the most common cancer of the urinary tract and is the ninth most common cancer among men, accounting for approximately 330,000 new cases and 130,000 deaths per year worldwide [1]. In the United States, the Netherlands and Belgium, bladder cancer is rated among the top five of most frequent cancers in males $[1,2,3]$. Bladder cancer is considerably more common in men than in women, but still approximately 60,000 women are diagnosed with the disease every year worldwide [1]. Like many solid tumours, bladder cancer incidence increases with age. Tumours of the bladder rarely occur before the age of 40-50, arising most commonly in the seventh decade of life [3]. The incidence of bladder cancer varies considerably among countries $[3,4]$. In general, the highest incidence rates for bladder cancer are found in the developed countries of Western Europe, North America and Australia; relatively low rates are found in the Far Eastern countries [1]. Since the world population is increasing and given the ageing population in the world, the incidence of bladder cancer will probably increase in the next decades. Therefore, prevention of bladder cancer, just as other forms of cancer, should continue to be of public interest.

About $90 \%$ of bladder cancers are transitional cell carcinomas, cancers that begin in the urothelial cell lining. About $80 \%$ of bladder tumours are confined to the bladder mucosa, the so-called superficial tumours, and $20 \%$ invade the muscle layer [5]. Haematuria, pain during urination and frequent urination are the most common symptoms of both types of cancer [6,7]. However, the management and prognosis of these cancers are completely different: superficial tumours are fairly benign, and invasive tumours are highly malignant. Depending on its stage and grade, bladder cancer may be treated with surgery, radiation therapy, (local) chemotherapy, or (local) immunotherapy. 
Along with lung cancer, bladder cancer was one of the earliest cancers to undergo serious epidemiologic investigation. As a consequence, some important causes of bladder cancer such as cigarette smoking, occupational exposure, and chronic infections with schistosoma haematobium have been known for decades. At present, evidence on dietary factors is also accumulating. The recent controversy concerning the influence of fluid consumption and diet on the risk of bladder cancer points to some of the still unanswered questions about the aetiology of the disease. Avoidance of hazardous behaviour (e.g. by means of health education and promotion) is possibly one of the most effective strategies in bladder cancer prevention. In this paper we evaluate three behavioural factors that are potentially associated with bladder cancer risk: smoking, beverage consumption, and diet.

\section{Data sources}

Primary epidemiologic studies were identified through computerised database searches for systematic reviews, follow-up studies, case-control studies, ecological studies and controlled trials published from 1966 to August 2003 and through reference checking [8]. We systematically reviewed the effects of smoking, beverage consumption, and diet and summarised their association with bladder cancer in levels of evidence and levels of association based on the results of previous literature and specifically on the ongoing Netherlands Cohort Study on diet and cancer (NLCS). The NLCS is the largest prospective cohort study to date conducted to investigate risk factors of bladder cancer.

The NLCS was initiated in 1986 with 120,852 men and women aged 55-69 years [9]. The subjects originated from 204 municipal population registries throughout the country. Data regarding potential risk factors for cancer were collected by means of a self-administered questionnaire. Follow-up for incident bladder cancer was established by record linkage to all regional cancer registries in The Netherlands and with the national pathology register (PALGA) [10]. For efficiency purposes, the case cohort approach was used for data processing and analysis [11, 12]. Following this approach, a subcohort of 3,500 subjects (1,688 men and 1,812 women) was randomly sampled from the cohort after the baseline exposure measurement. During a follow-up period of 6.3 years (September 1986-December 1992), 619 incident bladder cancer cases were detected. To date, six papers from the NLCS have described the associations between smoking, beverage consumption, diet $[13,14,15,16,17,18]$ and bladder cancer.

\section{Levels of evidence and levels of association}

A rating system, adapted from the World Cancer Research Fund [19], has been used to summarise the level of scientific evidence for these risk factors; it consists of four levels: convincing, probable, possible, and no evidence. The rating has been based on the number of epidemiologic studies showing consistent associations and whether or not supportive mechanistic evidence is present (Table 1).

The level of association across cohort studies is categorised as substantially increased risk $(R R \geq 2.5)$, moderately increased risk $(1.5 \leq \mathrm{RR}<2.5)$, slightly (or small) increased risk $(1.2 \leq \mathrm{RR}<1.5)$, no association $(0.8 \leq \mathrm{RR}<1.2)$, slightly (or small) decreased risk $(0.7 \leq \mathrm{RR}<0.8)$, moderately decreased risk $(0.4 \leq$ $R R<0.7)$, and substantially decreased risk $(R R<0.4)$. The level of association is estimated based on the previous results of case-control and cohort studies. Apart from previously published meta-analyses, the results were not further statistically pooled because too much heterogeneity in populations, designs, and effect measures occurred between the studies. We constructed a matrix in which the levels of evidence were combined with the levels of association (Table 2).

For each risk factor with probable or convincing evidence for a moderately or substantially altered bladder cancer risk, the etiologic fraction was calculated based on the level of association and the prevalence of exposure in the subcohort of the NLCS. The subcohort serves as a representative sample $(n=3,500)$ of the Dutch adult population [9]. The etiologic fraction-or population attributable risk - is the proportion of the bladder cancer cases for which a specific exposure contributed to the disease aetiology [20].

\section{Cigarette, cigar, pipe, and environmental smoking}

We will only briefly outline the impact of cigarette, cigar, pipe, and environmental smoking because this is also reported by Sommer et al. [20a].

Previous epidemiologic studies

\section{Cigarette smoking}

During the last four decades, many epidemiologic studies $[21,22,23,24]$ and reviews $[19,25,26,27,28,29$, $30,31,32,33]$ have consistently shown that cigarette smoking substantially increases the risk of bladder cancer. In a recent meta-analysis of 43 published casecontrol and cohort studies, we estimated that current

Table 1 Levels of evidence for etiological risk factors for disease

\begin{tabular}{|c|c|c|}
\hline $\begin{array}{l}\text { Number of epidemiologic } \\
\text { studies showing consistent } \\
\text { associations }\left(\mathrm{N}_{\text {study }}\right)\end{array}$ & $\begin{array}{l}\text { Supportive } \\
\text { mechanistic } \\
\text { evidence }^{\mathrm{a}}\end{array}$ & $\begin{array}{l}\text { No supportive } \\
\text { mechanistic } \\
\text { evidence }^{b}\end{array}$ \\
\hline $\begin{array}{l}\mathrm{N}_{\text {study }} \geq 15 \\
5 \leq \mathrm{N}_{\text {study }}<15 \\
1 \leq \mathrm{N}_{\text {study }}<5 \\
\mathrm{~N}_{\text {study }}=0\end{array}$ & $\begin{array}{l}\text { Convincing } \\
\text { Probable } \\
\text { Possible } \\
\text { No evidence }\end{array}$ & $\begin{array}{l}\text { Probable } \\
\text { Possible } \\
\text { Possible } \\
\text { No evidence }\end{array}$ \\
\hline
\end{tabular}

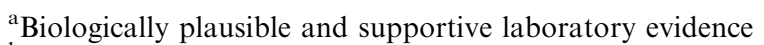

${ }^{\mathrm{b}}$ Biologically not plausible or no supportive laboratory evidence 
Table 2 Levels of evidence and levels of association for risk factors (exposed vs. not exposed) for urinary bladder cancer

\begin{tabular}{llll}
\hline Evidence & Convincing $^{1}$ & Probable $^{2}$ & Possible $^{3}$ \\
\hline $\begin{array}{l}\text { Substantially increased risk } \\
\text { Moderately increased risk }^{\mathrm{b}}\end{array}$ & Cigarette smoking & - & - \\
Slightly increased risk & - & - & - \\
& Alcohol consumption* & - & $\begin{array}{l}\text { Cigar smoking } \\
\text { Pipe smoking } \\
\text { Environmental smoking } \\
\text { No association }\end{array}$ \\
& & & Total fluid consumption \\
& - & Coffee consumption & Folate intake \\
Tlightly decreased risk & & Tea consumption & \\
Moderately Decreased risk & & Vegetable consumption & \\
Substantially decreased risk & & Vitamin A intake* & \\
\hline
\end{tabular}

${ }^{1}$ Convincing: $\geq 15$ well designed epidemiologic studies showing consistent associations $\left(\mathrm{N}_{\text {study }}\right)$ and supportive mechanistic evidence, ${ }^{2}$ Probable: $5 \leq \mathrm{N}_{\text {study }}<15$ and supportive mechanistic evidence, or $\mathrm{N}_{\text {study }} \geq 15$ and no supportive mechanistic evidence. ${ }^{3}$ Possible: $5 \leq \mathrm{N}_{\text {study }}<15$ and supportive mechanistic evidence, or $1 \leq \mathrm{N}_{\text {study }}<5$

cigarette smokers have an approximately threefold higher risk of bladder cancer than non-smokers [21]. The age- and gender-adjusted summary odds ratios for current and former cigarette smokers compared with those for nonsmokers were $3.33(95 \%$ confidence interval [95\% CI], 2.63-4.21) and 1.98 (95\% CI 1.72-2.29), respectively. A positive dose-response relationship has been found with both the number of cigarettes smoked per day and the number of years smoked. Age at first exposure and cessation of cigarette smoking were inversely associated with bladder cancer risk [21].

\section{Cigar, pipe, and environmental smoking}

The evidence of an association between bladder cancer risk and cigar $[34,35,36,37,38,39]$ and pipe $[34,35,36$, $37,38,39,40]$ smoking is not often reported $(\mathrm{n}=7$ and 8 , respectively), inconsistent, and generally weaker than the association with cigarette smoking [25, 27, 31, 33]. Only two case-control studies investigated the association between environmental smoking and bladder cancer risk [35, 41]. These studies have reported small increased risks for those exposed to environmental smoking compared with those not exposed to environmental smoking $(0.6 \leq \mathrm{RR}<1.6)$.

Netherlands cohort study

\section{Cigarette smoking}

In the Netherlands Cohort Study these associations were investigated in more detail [18]. From this study we concluded that the above-mentioned associations of cigarette smoking characteristics with bladder cancer risk were largely attributable to cigarette smoking duration and that these associations were independent of differences in tumour invasiveness or morphology. Furthermore, the tar and nicotine content of cigarettes, and filter-tip usage

\author{
${ }^{\mathrm{a}}(\mathrm{RR} \geq 2.5), \quad{ }^{\mathrm{b}}(1.5 \leq \mathrm{RR}<2.5),{ }^{\mathrm{c}}(1.2 \leq \mathrm{RR}<1.5),{ }^{\mathrm{d}}(0.8 \leq \mathrm{RR}<$ \\ $1.2),{ }^{\mathrm{e}}(0.7 \leq \mathrm{RR}<0.8),{ }^{\mathrm{f}}(0.4 \leq \mathrm{RR}<0.7),{ }^{\mathrm{g}}(\mathrm{RR}<0.4)$, comparing \\ exposure vs. no exposure \\ *for men; the risk related to alcohol consumption for women \\ remains unclear, \\ **and carotenoids
}

were only weakly associated with bladder cancer risk. Cigarette smoking cessation and age at first exposure were not associated with bladder cancer risk after taking into account the total smoking duration [18]. These results were comparable with the overall results from the metaanalysis [21] and the pooled analyses [22, 23].

\section{Cigar, pipe, and environmental smoking}

We confirmed a substantially increased risk of bladder cancer for current cigar (RR 2.88, 95\% $1.68-4.93$ ) and pipe smokers (RR 3.03, 95\% 1.67-5.50) versus those who never smoke tobacco; however, these risks were confounded by cigarette smoking and disappeared after adjustment for cigarette smoking [18].

\section{Mechanistic evidence}

\section{Cigarette smoking}

The precise mechanism by which cigarette smoking causes bladder cancer has yet to be determined. It seems most likely that the risk of bladder cancer is related to some of the large number of chemicals present in smoke. 2-Naphthylamine and 4-aminobiphenyl are the leading candidates as the specific etiologic agents [27, 32, 33, 42, 43]. Besides the effect that many compounds in cigarettes can cause carcinogenic events in the bladder, cigarette smoking has been found to increase proliferation, as evidenced by hyperplasia of the bladder epithelium [33].

\section{Cigar, pipe, and environmental smoking}

An association between cigar and pipe smoking and the risk of bladder cancer is biologically plausible since the smoke of both types of tobacco contains many of the 
same substances as present in cigarette tobacco. However, cigar and pipe smokers inhale less than cigarette smokers, which might explain an increased cancer incidence for cigar and pipe smokers in local areas of the human body (e.g. head/neck cancer) and no increased risk through a systemic effect (e.g. bladder cancer). Data from experimental studies also support the hypothesis that non-smokers might be exposed to potential carcinogens through the cigarette smoke of others [44]. Mutagens have been detected in the blood and urine of passive smokers [44, 45].

\section{Conclusions}

Judging the evidence, we conclude that there is convincing evidence from many epidemiologic and mechanistic studies that cigarette smoking substantially increases the risk of bladder cancer (Table 2). Although an association with cigar and pipe smoking could be mechanistically explained, there is also biologically plausible evidence for no association with bladder cancer risk. The results from many epidemiologic studies concerning cigar and pipe smoking are not consistent. We therefore conclude that a small increased risk for cigar and pipe smoking is only possible. An increased risk through exposure to environmental smoking is supported by mechanistic evidence, although more epidemiologic studies are needed to confirm this. A small association between exposure to environmental smoking and bladder cancer risk possibly exists (Table 2).

\section{Etiologic Fraction}

Since there is convincing evidence for a substantially increased risk of bladder cancer for cigarette smokers, the etiologic fraction of cigarette smoking was calculated. Cigarette smoking accounts for $23 \%$ of all female bladder cancer, whereas in men $50 \%$ of the disease is attributable to cigarette smoking.

\section{Total fluid, alcohol, coffee, and tea consumption}

Previous epidemiologic studies

\section{Total fluid consumption}

Previous case-control and cohort studies on total fluid consumption and bladder cancer risk have shown inconsistent results. Seven case-control studies reported positive associations (1.4 $\leq \mathrm{RR} 37,46,47,48,49,50]$, whereas three other case-control studies found no association $(0.8 \leq \mathrm{RR} 51,52,53]$. Only one case-control study reported an inverse association between total fluid consumption and bladder cancer risk in women, but not in men [57]. Apart from the Netherlands Cohort Study, two cohort studies to date were conducted to investigate this association $[55,56]$. One cohort study did not find an association between fluid consumption and bladder cancer risk [55], whereas the other reported an inverse association of total fluid consumption $(\mathrm{RR}=0.5)$ [56].

\section{Alcohol consumption}

Previous studies also have investigated associations of the consumption of specific fluids (i.e. alcohol, coffee and tea) with bladder cancer risk. We have concluded, based on a meta-analysis of 30 epidemiologic studies [57] that the available data suggest a slightly increased cigarette smoking-adjusted risk of bladder cancer from alcohol consumption for men, which, however, is small and not statistically significant $(\mathrm{RR}=1.3$, CI $0.9-2.0$, comparing any alcohol consumption with no alcohol consumption) [57]. The risk related to alcohol consumption for women remains unclear [57].

\section{Coffee consumption}

Narrative reviews on coffee consumption and bladder cancer concluded that the epidemiologic evidence was consistent with a small positive association, possibly due to confounding by smoking $[19,31,58,59,60]$. Most conclude that further research is necessary to decide whether the association is causal or due to confounding by smoking. In our meta-analysis the available evidence based on 14 epidemiologic studies suggested a very small and borderline significant increased risk for coffee consumers remaining after adjustment for age, cigarette smoking and sex $(\mathrm{RR}=1.2$, CI 1.0-1.4), although this was predominantly based on case-control data [57].

\section{Tea consumption}

We found in a systematic review based on seven epidemiologic studies that current consumption of tea seems not to be related to an increased risk of bladder cancer. The summary odds ratio for tea drinking compared with no tea drinking was 1.0 (CI 0.9-1.1) [57].

\section{Netherlands Cohort Study}

\section{Total fluid consumption}

In the Netherlands Cohort Study the association between fluid intake and bladder cancer risk was examined in detail $[15,16]$. In this study, neither total fluid consumption nor total water intake were associated with bladder cancer risk [15].

\section{Alcohol consumption}

The positive association between alcohol consumption and male bladder cancer found in the Netherlands 
Cohort Study was small and independent of differences in tumour invasiveness and morphology [16]. We found no association between alcohol consumption and bladder cancer risk for women [16].

\section{Coffee consumption}

The results of the Netherlands Cohort Study supported a small positive association between coffee consumption and male bladder cancer, mainly confined to the higher consumption categories after adjusting for cigarette smoking [15]. For women, an inverse association was found [15].

\section{Tea consumption}

Tea consumption was inversely associated with bladder cancer for both men and women in the Netherlands Cohort Study, irrespective of consumption frequency [15].

\section{Mechanistic evidence}

\section{Total fluid consumption}

The urogenous-contact hypothesis associates the development of bladder cancer with prolonged exposure to carcinogens in urine $[56,61]$. High consumption of fluids may reduce this exposure by diluting the urine and reducing contact time through increased frequency of urination. However, total fluid consumption has also been hypothesised to increase the risk of bladder cancer by increasing the workload of the bladder or by exposing the bladder to specific fluids that contain carcinogens $[50,52]$.

\section{Alcohol consumption}

Also, several possible mechanisms to explain carcinogenesis by alcohol intake have been postulated. Heavy alcohol consumption may, through its effect on the liver and hepatic enzyme systems, reduce the detoxification of carcinogenic substances [62]. Furthermore, ethanol slows down protein synthesis. One consequence of this is that cell repair mechanisms might be inhibited, which could lead to malignant changes [63, 64, 68]. Ethanol might improve the permeability of membranes to carcinogens and might enhance carcinogenic activity [64, 65, 66]. Other explanations include the effect of ethanol on cell proliferation, possibly caused by the ethanol metabolite acetaldehyde [33, 62, 64, 65].

\section{Coffee consumption}

Caffeine and other substances in coffee could have direct or indirect metabolic effects and modify concentrations of carcinogenic or anticarcinogenic substances in bladder epithelium [59]. Since most of these substances or their metabolites are excreted by the bladder, they have to come into contact with the mucous membrane of the bladder first. However, there are no clear-cut conclusions from animal studies on the potential carcinogenic effects of coffee. According to most animal studies, coffee and caffeine do not have a carcinogenic effect in laboratory animals, nor can they induce tumours, or potentiate or inhibit the carcinogenic effects of other substances [59]. However, Lopez-Abente et al. have suggested that caffeine may act as an inducer of CYP1A2 (a cytochrome P450 enzyme), which may be related to risk of bladder cancer through metabolic activation of aromatic amines and formation of compounds that in turn lead to formation of DNA adducts [67]. High consumption of coffee (more than four cups of coffee per day) has been observed to lead to such induction in N-oxidation activity, dependent on CYP1A2 [67].

\section{Tea consumption}

Evidence from animal studies shows that certain compounds present in tea may have inhibitory effects on bladder tumour formation and growth. This inhibitory activity is believed to be mainly due to the antioxidative and possibly antiproliferative effects of polyphenol compounds (e.g. flavonoids) [68, 69, 70, 71, 72]. It has been pointed out that no other agent tested for possible chemoprevention effects in animal models has elicited such strong activity as tea and its components at concentrations usually consumed by humans [70].

\section{Conclusions}

Although epidemiologic and mechanistic evidence are not consistent, the weight of evidence is not in favour of a protective effect of fluid intake. We, therefore, tentatively conclude that it is possible that total fluid intake is not associated with bladder cancer risk (Table 2). There is convincing evidence for a small positive association between alcohol consumption and bladder cancer risk in men. The risk related to alcohol consumption for women remains unclear. Most epidemiologic and mechanistic studies were not supportive for an increased bladder cancer risk for coffee consumers. Probably there is no association between coffee consumption and bladder cancer. If an increased risk exists, it is probably weak and mainly confined to the higher consumption categories. Although there is supportive mechanistic evidence for a negative association between tea consumption and bladder cancer risk, most epidemiologic studies could not confirm this. We conclude that tea consumption is probably not associated with the risk of bladder cancer (Table 2). 


\section{Fruit, vegetable, vitamin (A, C, E and folate), and selenium intake}

Previous epidemiologic studies

\section{Fruit and vegetable consumption}

Recently, a meta-analysis on seven case-control studies and three cohort studies concerning bladder cancer and fruit consumption reported small elevated smoking-adjusted bladder cancer risks among subjects with low fruit consumption vs. subjects with high fruit consumption $(\mathrm{RR}=1.5, \mathrm{CI} 1.3-1.7)$ [73]. The same meta-analysis also found a small positive smoking-adjusted association between vegetable consumption and bladder cancer risk comparing high vs. low consumption $(\mathrm{RR}=1.2$, CI 1.0-1.4) [73].

\section{Vitamin intake}

Furthermore, the meta-analysis did not find different risks of bladder cancer in relation with diets low in retinol or $\beta$ carotene compared with diets high in retinol and $\beta$-carotene $(\mathrm{RR}=1.0, \mathrm{CI} 0.8-1.2)$ in seven case-control studies and three cohort studies [73]. Two other prospective studies that were published more recently also found no association between supplemental and dietary vitamin A intake $[74,75]$. The majority of epidemiologic studies on dietary vitamin $\mathrm{C}$ intake reported relative risks around unity for high vs. low intake [51, 76, 77, 78, 79, 80]. Most epidemiologic studies reported inverse associations between supplemental intakes of vitamin $\mathrm{E}$ in relation to bladder cancer risk $(0.5 \leq \mathrm{RR} 75,78,81]$. Dietary vitamin E intake was also inversely associated with bladder cancer in one study [76]. The epidemiologic evidence relating dietary folate and the risk of bladder cancer is limited. One case-control study found an inverse association with bladder cancer risk $(\mathrm{RR}=0.5$, comparing highest with lowest quartiles of intake) [81], whereas one cohort study did not find an association between total folate intake and bladder cancer incidence [75].

\section{Selenium intake}

Apart from the Netherlands Cohort Study, four prospective studies investigated the association between serum or toenail selenium and bladder cancer risk [82, 83, 84, 85]. Most studies found a moderate inverse association between selenium status and bladder cancer risk $(0.3 \leq \mathrm{RR} 84]$.

Netherlands cohort study

\section{Fruit and vegetable consumption}

In the Netherlands Cohort Study, an inverse association was found between bladder cancer risk and fruit consumption ( $\mathrm{RR}=0.7$, CI $0.5-1.0$, comparing highest vs. lowest quintile of consumption). This protective effect was mainly confined to invasive transitional cell carcinomas, irrespective of tumour morphology [13]. The results showed that total vegetable consumption was not associated with bladder cancer risk $(\mathrm{RR}=0.9$, CI 0.7 1.3 , comparing highest vs. lowest quintile of consumption) [13].

\section{Vitamin intake}

We have concluded furthermore that dietary or supplemental intake of vitamin $\mathrm{A}$, vitamin $\mathrm{C}$, vitamin $\mathrm{E}$, and dietary intake from folate and most carotenoids were not associated with bladder cancer risk [14]. Only the carotenoid $\beta$-cryptoxanthin appeared to be inversely associated with bladder cancer risk when comparing highest versus lowest quintiles of intake $(R R=0.7$, CI 0.5-1.0), which appeared to be independent of different tumour invasiveness and morphology [14]. Citrus fruits are the main sources of $\beta$-cryptoxanthin.

\section{Selenium intake}

The results of the Netherlands Cohort Study showed a moderate inverse association between base-line toenail selenium and subsequent bladder cancer risk $(\mathrm{RR}=0.7$, CI 0.5-0.9). The association was most pronounced in ex-smokers and mainly confined to invasive carcinomas of the bladder [17].

Mechanistic evidence

\section{Fruit and vegetable consumption}

There are many candidate agents in fruit and vegetables that potentially influence bladder cancer risk. Some possible anticarcinogenic mechanisms of substances in fruits and vegetables include antioxidant effects, effects on cell differentiation, increased activity of enzymes that detoxify carcinogens, blocked formation of nitrosamines, preserved integrity of intracellular matrices, effects on DNA methylation, maintenance of normal DNA repair, increased apoptosis of cancer cells and decreased cell proliferation [86].

\section{Vitamin intake}

Retinol is the physiologically active form of vitamin A and can be derived from some carotenoids. Carotenoids have antioxidant properties and may inhibit carcinogenesis by preventing DNA damage induced by free radicals. Furthermore, vitamin A is important for cell differentiation and since lack of differentiation is a feature of cancer cells, a protective effect of vitamin A on cancer development may be expected [87, 88, 89]. Vitamin $\mathrm{C}$ is mostly known for its antioxidant capacity [87] and its ability to prevent formation of nitrosamine and 
other $N$-nitroso compounds [90]. Like vitamin C, vita$\min \mathrm{E}$ is an intracellular antioxidant and can inhibit nitrosation [19, 88, 91]. Furthermore, vitamin $\mathrm{E}$ has the capacity to keep selenium in reduced state [87]. Folate is essential for methylation reactions in the human body. Reduced methylation of DNA may contribute to loss of normal controls on proto-oncogene expression. Folate deficiency causes massive incorporation of uracil into human DNA and chromosome breaks. Such breaks could contribute to an increased risk of cancer $[92,93]$.

\section{Selenium intake}

Several hypotheses have been proposed to explain the inhibition of tumourgenesis by selenium, including alterations in carcinogen metabolism, effects on the endocrine and immune systems, production of cytotoxic selenium metabolites, inhibition of protein synthesis, inhibition of specific enzymes, inhibition of tumour growth, stimulation of apoptosis and protection against oxidative stress involving the function of selenium as a constituent in the antioxidant enzyme glutathione peroxidase $[83,85,88,94,95,96,97,98]$.

\section{Conclusions}

We conclude that high consumption of total fruit is probably associated with a small decrease in bladder cancer risk (Table 2). There is probably no association between total vegetable intake and bladder cancer risk, although an influence of specific vegetables on bladder cancer risk cannot be excluded. Although the mechanistic evidence is in favour of an inverse association between vitamin $\mathrm{A}$, carotenoids, vitamin $\mathrm{C}$ intake and subsequent bladder cancer risk, the epidemiologic evidence does not support this. We tentatively conclude that vitamin $\mathrm{A}$, carotenoids, and vitamin $\mathrm{C}$ intake are probably not associated with bladder cancer risk. Few epidemiologic studies and mechanistic evidence support a possibly moderate inverse association between vitamin $\mathrm{E}$ intake and bladder cancer risk. The epidemiologic evidence for the intake of folate is still limited and conflicting. From a mechanistic point of view, however, a protecting effect from folate intake is plausible. Until more epidemiologic studies are conducted, we conclude that there is possible evidence that folate is not associated with bladder cancer risk. There probably is a moderate inverse association between selenium intake and bladder cancer risk (Table 2).

\section{Etiologic fraction}

Since there is probable evidence for a moderately decreased risk of bladder cancer for subjects with high selenium status, the etiologic fraction was calculated based on the results of the Netherlands Cohort Study. If toenail selenium status of subjects in the two lowest quintiles of the Dutch population $(\leq 0.530 \mu \mathrm{g} / \mathrm{g})$ could be increased to the level of the third quintile $(0.530$ $\leq 0.573 \mu \mathrm{g} / \mathrm{g}$ ), approximately $20 \%$ less bladder cancer could be attributable to selenium deficiency.

\section{Future research: gene environment}

\section{Polymorphism environment}

Epidemiology has traditionally evaluated environmental risk factors such as smoking, beverage consumption, and diet, which has provided an important contribution to our knowledge on bladder cancer aetiology. Although cigarette smoking has been identified as the most important risk factor for bladder cancer, knowledge of this and other environmental risk factors and possible pathways alone is probably not sufficient to completely explain the incidence of bladder cancer. Epidemiologists could extend their study designs to studies designed to evaluate the combined effect of environmental factors (e.g. cigarette smoking) and genetic factors. This combination might explain more variation in bladder cancer incidence than using these environmental risk factors alone.

For example, N-acetyltransferase 2 (NAT2) or glutathione S-transferase Mul (GSTMI) polymorphisms may modify the metabolism of tobacco carcinogens. Slow acetylation or lack of GSTM1 activity (which is present in $50 \%$ of Caucasians) might result in a higher concentration of tobacco carcinogens in the bladder and consequently enhance the risk of bladder cancer among cigarette smokers $[99,100,101]$. The enzyme coded by the gene CYP2D6, debrisoquine hydroxylase, is hypothesised to be involved in the nicotine metabolism. However, previously conducted studies have not associated variation in this genotype with an increased bladder cancer risk [100, 101, 102]. The enzyme coded by the CYPlAl gene (one of the cytochrome P-450 genes), aryl hydroxylase, may be involved in the metabolic activation of polycyclic arylhydrocarbons [100]. Through further epidemiologic research on polymorphism-environment interaction it might become possible to identify individuals with a higher susceptibility of bladder cancer after exposure to potential carcinogens compared with the general population. Such a study is currently underway in the Belgian province of Limburg (E Kellen, MP Zeegers, F Buntinx, Bladder cancer in Limburg: a discovery of determinants through epidemiological research, submitted for publication).

\section{Mutation environment}

Parallel to these new genetic epidemiologic approaches to understanding bladder cancer aetiology, there have been important advances in understanding molecular genetics of bladder cancer, i.e. in identifying the series of somatic changes in bladder cells that in combination lead to the development of the malignant phenotype [32]. Genetic 
differences seem to exist between papillary and non-papillary carcinomas. The high-grade, non-papillary transitional cell carcinoma usually contains a defect in chromosome 17, which represents an abnormality in the p53 gene. By contrast, changes in chromosome 9 are associated with superficial papillary tumours [33]. In the Netherlands Cohort Study, we have found different associations with some of the investigated risk factors depending on tumour invasiveness and morphology. It appeared that a protective effect of toenail selenium level and fruit consumption was mainly confined to invasive transitional cell carcinomas, irrespective of tumour morphology [13, 17]. However, associations for cigarette smoking, and alcohol intake were independent of different tumour invasiveness and morphology [16, 18]. It might be interesting for epidemiologists to investigate associations between specific environmental risk factors and specific mutations that lead to different morphology and invasiveness of bladder cancer.

\section{Conclusion}

\section{Convincing}

Based on the results of previous epidemiologic studies and mechanistic evidence, we conclude that the most important risk factor for bladder cancer is cigarette smoking. Prevention of cigarette smoking would result in a decrease of $50 \%$ of male bladder cancer cases and $23 \%$ of female bladder cancer cases. Alcohol consumption is the only other convincing risk factor for bladder cancer, although previous research suggests that the risk elevation for alcohol consumers is very small, which might not be of practical importance (Table 2).

\section{Probable}

There is probably no association between coffee, tea, vitamin $\mathrm{A}$ and $\mathrm{C}$ intake and subsequent bladder cancer risk and a negative association with fruit consumption and selenium intake (Table 2).

\section{Possible}

It is possible that cigar, pipe and passive smoking slightly increase bladder cancer risk, that total fluid consumption and folate intake are not associated with bladder cancer risk, and that vitamin E intake decreases bladder cancer risk. Further research is needed to confirm these conclusions (Table 2).

\section{References}

1. Steward BW, Kleinhaus P (2003) World Cancer Report. WHO-IARC, Lyon
2. Lousbergh D, et al (2003) Incidence of cancer in the Belgian province of Limburg. LIKAS, Hasselt

3. Visser O, Coeberg J, Dijck van J, Siesling S (2002) Incidence of cancer in the Netherlands 1998. Association of comprehensive cancer centres, Utrecht

4. Schottenfeld D, Fraumeni JF (1996) Cancer epidemiology and prevention. Oxford University Press, New York, Oxford

5. van der Meijden (1998) APM bladder cancer. British Medical Journal 317:1366-1369

6. Bruyninckx R, Buntinx F, Aertgeerts B, Van Casteren V (2003) The diagnostic value of macroscopic haematuria for the diagnosis of urological cancer in general practice. Br J Gen Pract 53:31-35

7. Buntinx F, Wauters H (1997) The diagnostic value of macroscopic haematuria in diagnosing urological cancers: a metaanalysis. Fam Pract 14:63-68

8. van der Windt DA, Zeegers MP, Kemper HC, Assendelft WJ, Scholten RJ (2000) Practice of systematic reviews. VI. Searching, selection and methodological evaluation of etiological research. Ned Tijdschr Geneeskd 144:1210-1214

9. van den Brandt PA, et al (1990) A large-scale prospective cohort study on diet and cancer in the Netherlands. J Clin Epidemiol 43:285-95

10. van den Brandt PA, Schouten LJ, Goldbohm RA, Dorant E, Hunen PHM (1990) Development of a record linkage protocol for use in the Dutch cancer registry for epidemiological research. Int J Epidemiol 19:553-558

11. Barlow WE (1994) Robust variance estimation for the casecohort design. Biometrics 50:1064-1072

12. Barlow WE, Ichikawa L, Rosner D, Izumi S (1999) Analysis of case-cohort designs. J Clin Epidemiol 52:1165-1172

13. Zeegers MP, Goldbohm RA, van den Brandt PA (2001) Consumption of vegetables and fruits and urothelial cancer incidence: a prospective study. Cancer Epidemiol Biomarkers Prev 10:1121-1128

14. Zeegers MP, Goldbohm RA, van den Brandt, PA (2001) Are retinol, vitamin $\mathrm{C}$, vitamin $\mathrm{E}$, folate and carotenoids intake associated with bladder cancer risk? Results from the Netherlands Cohort Study. Br J Cancer 85:977-983

15. Zeegers MP, Dorant E, Goldbohm RA, van den Brandt PA (2001) Are coffee, tea, and total fluid consumption associated with bladder cancer risk? Results from the Netherlands Cohort Study. Cancer Causes Control 12:231-238

16. Zeegers MP, Volovics A, Dorant E, Goldbohm RA, van den Brandt PA (2001) Alcohol consumption and bladder cancer risk: results from The Netherlands Cohort Study. Am J Epidemiol 153:38-41

17. Zeegers MP, Goldbohm RA, Bode P, van den Brandt PA (2002) Prediagnostic toenail selenium and risk of bladder cancer. Cancer Epidemiol Biomarkers Prev 11:1292-1297

18. Zeegers MP, Goldbohm RA, van den Brandt PA (2002) A prospective study on active and environmental tobacco smoking and bladder cancer risk (The Netherlands). Cancer Causes Control 13:83-90

19. World Cancer Research Fund \& American Institute for Cancer Research (1997) Food, nutrition and the prevention of cancer: a global perspective. Banta Book Group, Menasha

20. Rothman K, Greenland S (1998) Modern epidemiology. Lippincott-Raven Publishers, Philadelphia

20a. Sommer F, Klotz T, Schmitz-Dräger BJ (2004) Lifestyle issues and genitourinary tumours. World $\mathbf{J}$ Urol (in press) DOI 10.1007/s00345-003-0379-3

21. Zeegers MP, Tan FE, Dorant E, van Den Brandt PA (2000) The impact of characteristics of cigarette smoking on urinary tract cancer risk: a meta-analysis of epidemiologic studies. Cancer 89:630-639

22. Brennan P, et al (2000) Cigarette smoking and bladder cancer in men: a pooled analysis of 11 case-control studies. Int $\mathbf{J}$ Cancer 86:289-294

23. Brennan P, et al (2001) The contribution of cigarette smoking to bladder cancer in women (pooled European data). Cancer Causes Control 12:411-417 
24. Castelao JE, et al (2001) Gender- and smoking-related bladder cancer risk. J Natl Cancer Inst 93:538-545

25. Matanoski GM, Elliott EA (1981) Bladder cancer epidemiology. Epidemiol Rev 3:203-229

26. Morrison AS (1984) Control of cigarette smoking in evaluating the association of coffee drinking and bladder cancer. In: MacMahon B, Sugimura T (eds) Coffee and health. Cold Spring Harbor Laboratory, Spring Harbor, pp 127-136

27. Dolin PJ (1991) An epidemiological review of tobacco use and bladder cancer. J Smoking Related Dis 2:129-143

28. Silverman DT, Hartge P, Morrison AS, Devesa SS (1992) Epidemiology of bladder cancer. Hematol Oncol Clin North Am 6:1-30

29. Shirai T (1993) Etiology of bladder cancer. Semin Urol 11:113-126

30. Shirai T, et al (1995) The etiology of bladder cancer: are there any new clues or predictors of behavior? Int $\mathbf{J}$ Urol 2[Suppl 3]: $64-75$

31. Silverman DT, Morrison AS, Devesa SS (1996) Bladder cancer. In: Schottenfeld D, Fraumeni JF (eds) Cancer epidemiology and prevention. Oxford University Press, New York, Oxford, pp 1156-79

32. Ross RK, Jones PA, Yu MC (1996) Bladder cancer epidemiology and pathogenesis. Semin Oncol 23:536-545

33. Johansson SL, Cohen SM (1997) Epidemiology and etiology of bladder cancer. Semin Surg Oncol 13:291-298

34. Howe GR, et al (1980) Tobacco use, occupation, coffee, various nutrients, and bladder cancer. J Natl Cancer Inst 64:701713

35. Burch JD, et al (1989) Risk of bladder cancer by source and type of tobacco exposure: a case-control study. Int J Cancer 44:622-628

36. Jensen OM, Wahrendorf J, Blettner M, Knudsen JB, Sorensen BL (1987) The Copenhagen case-control study of bladder cancer: role of smoking in invasive and non-invasive bladder tumours. J Epidemiol Community Health 41:30-36

37. Claude J, et al (1986) Life-style and occupational risk factors in cancer of the lower urinary tract. Am J Epidemiol 124:578589

38. Hartge P, Hoover R, Kantor A (1985) Bladder cancer risk and pipes, cigars and smokeless tobacco. Cancer 15:901-906

39. Steineck G, Norell SE, Feychting M (1988) Diet, tobacco and urothelial cancer: a 14-year follow-up of 16,477 subjects. Acta Oncol 27:323-327

40. Morrison AS, et al (1984) An international study of smoking and bladder cancer. Journal d Urologie 131:650-654

41. Sandler DP, Everson RB, Wilcox AJ (1985) Passive smoking in adulthood and cancer risk. Am J Epidemiol 121:37-48

42. Morrison AS, Cole P (1976) Epidemiology of bladder cancer. Urol Clin North Am 3:13-29

43. Vineis P (1992) Epidemiological models of carcinogenesis: the example of bladder cancer. Cancer Epidemiol Biomarkers Prev 1:149-153

44. Sandler DP, Wilcox AJ, Everson RB (1985) Cumulative effects of lifetime passive smoking on cancer risk. Lancet 1:312315

45. Bos RP, Theuws JL, Henderson PT (1983) Excretion of mutagens in human urine after passive smoking. Cancer Lett 19:85-90

46. Jensen OM, Wahrendorf J, Knudsen JB, Sorensen BL (1986) The Copenhagen case-control study of bladder cancer. II. Effect of coffee and other beverages. Int J Cancer 37:651-657

47. Kunze E, Chang Claude J, Frentzel Beyme R (1992) Life style and occupational risk factors for bladder cancer in Germany. A case-control study. Cancer 69:1776-1790

48. Vena JE, et al (1993) Drinking water, fluid intake and bladder cancer in western New York. Arch Environ Health 48:191198

49. Cantor KP, et al (1987) Bladder cancer, drinking water source, and tap water consumption: a case-control study. J Natl Cancer Inst 79:1269-1279
50. Bianchi GD, et al (2000) Tea consumption and risk of bladder and kidney cancers in a population-based case-control study. Am J Epidemiol 151:377-383

51. Risch HA, et al (1988) Dietary factors and the incidence of cancer of the urinary bladder. Am J Epidemiol 127:1179-1191

52. Slattery ML, West DW, Robison LM (1988) Fluid intake and bladder cancer in Utah. Int J Cancer 42:17-22

53. Dunham LJ, Rabson AS, Steward HS, Frank A, Young JL (1968) Rates, interview, and pathology study of cancer of the urinary bladder in New Orleans, Louisiana. J Natl Cancer Inst 41:683-709

54. Wilkens LR, Kadir MM, Kolonel LN, Nomura AM, Hankin JH (1996) Risk factors for lower urinary tract cancer: the role of total fluid consumption, nitrites and nitrosamines, and selected foods. Cancer Epidemiol Biomarkers Prev 5:161-166

55. Mills PK, Beeson WL, Phillips RL, Fraser GE (1991) Bladder cancer in a low risk population: results from the Adventist Health Study. Am J Epidemiol 133:230-239

56. Michaud DS, et al Fluid intake and the risk of bladder cancer in men. N Engl J Med 340:1390-1397 (1999)

57. Zeegers MP, Tan FE, Goldbohm RA, van den Brandt PA (2001) Are coffee and tea consumption associated with urinary tract cancer risk? A systematic review and meta-analysis. Int $\mathbf{J}$ Epidemiol 30:353-362

68. World Health Organization (1991) IARC monographs on the evaluation of carcinogenic risks to humans: coffee, tea, mate, methylxanthines and methylgloxal. World Health Organization, Lyon

59. Nehlig A, Debry G (1996) Coffee and cancer: a review of human and animal data. World Rev Nutr Diet 79:185-221

60. Negri E, La Vecchia C (2001) Epidemiology and prevention of bladder cancer. Eur J Cancer Prev 10:7-14

61. Jones PA, Ross RK (1999) Prevention of bladder cancer N Engl J Med 340:1424-1426

62. Blot WJ (1999) Invited commentary: more evidence of increased risks of cancer among alcohol drinkers. Am J Epidemiol 150:1138-1140

63. Berger A (1998) Science commentary: why wine might be less harmful than beer and spirits. BMJ 317:848

64. Seitz HK, Simanowski UA (1988) Alcohol and carcinogenesis. Annu Rev Nutr 8:99-119

65. Garro AJ, Lieber CS Alcohol and cancer. Annu Rev Pharmacol Toxicol 30:219-49 (1990)

66. Freund G (1979) Possible relationships of alcohol in membranes to cancer. Cancer Res 39:2899-2901

67. Lopez-Abente G, Escolar A (2001) Tobacco consumption and bladder cancer in non-coffee drinkers. J Epidemiol Community Health 55:68-70

68. Yang CS, Wang ZY (1993) Tea and cancer. J Natl Cancer Inst 85:1038-1049

69. Goldbohm RA, Hertog MG, Brants HA, van Poppel G, van den Brandt PA (1996) Consumption of black tea and cancer risk: a prospective cohort study. J Natl Cancer Inst 88:93-100

70. Dreosti IE, Wargovich MJ, Yang CS (1997) Inhibition of carcinogenesis by tea: the evidence from experimental studies. Crit Rev Food Sci Nutr 37:761-770

71. Dreosti IE (1996) Bioactive ingredients: antioxidants and polyphenols in tea. Nutr Rev 54: S51-S58

72. Katiyar SK, Mukhtar H (1996) Tea consumption and cancer. World Rev Nutr Diet 79:154-184

73. Steinmaus CM, Nunez S, Smith AH (2000) Diet and bladder cancer: a meta-analysis of six dietary variables. Am J Epidemiol 151:693-702

74. Michaud DS, et al (2002) Intakes of fruits and vegetables, carotenoids and vitamins A, E, C in relation to the risk of bladder cancer in the ATBC cohort study. Br J Cancer 87:960-965

75. Michaud DS, et al (2000) Prospective study of dietary supplements, macronutrients, micronutrients, and risk of bladder cancer in US men [In Process Citation]. Am J Epidemiol 152:1145-1153 
76. Riboli E, et al (1991) Diet and bladder cancer in Spain: a multi-centre case-control study. Int J Cancer 49:214-219

77. Vena JE, et al (1992) Diet in the epidemiology of bladder cancer in western New York. Nutr Cancer 18:255-264

78. Shibata A, Paganini Hill A, Ross RK, Henderson BE (1992) Intake of vegetables, fruits, beta-carotene, vitamin $\mathrm{C}$ and vitamin supplements and cancer incidence among the elderly: a prospective study. Br J Cancer 66:673-679

79. Nomura AMY, Kolonel LN, Hankin JH, Yoshizawa CN (1991) Dietary factors in cancer of the urinary tract. Int J Cancer 48:199-205

80. Kolonel LN, Hinds MW, Nomura AM, Hankin JH, Lee J (1985) Relationship of dietary vitamin A and ascorbic acid intake to the risk for cancers of the lung, bladder, and prostate in Hawaii. Natl Cancer Inst Monogr 69:137-142

81. Bruemmer B, White E, Vaughan TL, Cheney CL (1996) Nutrient intake in relation to bladder cancer among middleaged men and women. Am J Epidemiol 144:485-495

82. Nomura A, Heilbrun LK, Morris JS, Stemmermann GN (1987) Serum selenium and the risk of cancer, by specific sites: case-control analysis of prospective data. J Natl Cancer Inst 79:103-108

83. Helzlsouer KJ, Comstock GW, Morris JS (1989) Selenium, lycopene, alpha-tocopherol, beta-carotene, retinol, and subsequent bladder cancer. Cancer Res 49:6144-6148

84. Knekt P, et al (1990) Serum selenium and subsequent risk of cancer among Finnish men and women. J Natl Cancer Inst $82: 864-868$

85. Garland M, et al (1995) Prospective study of toenail selenium and cancer among women. J Natl Cancer Inst 87:497505

86. Steinmetz KA, Potter JD (1996) Vegetables, fruit, and cancer prevention: a review. J Am Diet Assoc 96:1027-1039

87. Steinmetz KA, Potter JD (1991) Vegetables, fruit, and cancer. II. Mechanisms. Cancer Causes Control 2:427-442

88. Patterson RE, White E, Kristal AR, Neuhouser ML, Potter JD (1997) Vitamin supplements and cancer risk: the epidemiologic evidence. Cancer Causes Control 8:786-802

89. Kamat AM, Lamm DL (1999) Chemoprevention of urological cancer. J Urol 161:1748-1760
90. Birt DF (1986) Update on the effects of vitamins A, C, and E and selenium on carcinogenesis. Proc Soc Exp Biol Med 183:311-320

91. Knekt P, et al (1988) Serum vitamin E and risk of cancer among Finnish men during a 10-year follow-up. Am J Epidemiol 127:28-41

92. Glynn SA, Albanes D (1994) Folate and cancer: a review of the literature. Nutr Cancer 22:101-119

93. Blount BC, et al (1997) Folate deficiency causes uracil misincorporation into human DNA and chromosome breakage: implications for cancer and neuronal damage. Proc Natl Acad Sci U S A 94:3290-3295

94. Clark LC, et al (1996) Effects of selenium supplementation for cancer prevention in patients with carcinoma of the skin: a randomized controlled trial. JAMA 276:1957-1963

95. Salonen JT, Alfthan G, Huttunen JK, Puska P (1984) Association between serum selenium and the risk of cancer. Am J Epidemiol 120:342-349

96. Willett WC, et al (1983) Prediagnostic serum selenium and risk of cancer. Lancet 2:130-134

97. Virtamo J, et al (1987) Serum selenium and risk of cancer. A prospective follow-up of nine years. Cancer 60:145-148

98. Fan AM, Kizer KW (1990) Selenium: nutritional, toxicologic and clinical aspects. West J Med 153:160-167

99. Brockmoller J, Kerb R, Drakoulis N, Staffeldt B, Roots I (1994) Glutathione S-transferase M1 and its variants A and B as host factors of bladder cancer susceptibility: a case-control study. Cancer Res 54:4103-4111

100. Brockmoller J, Cascorbi I, Kerb R, Roots I (1996) Combined analysis of inherited polymorphisms in arylamine $\mathrm{N}$ - acetyltransferase 2, glutathione S-transferases $\mathrm{M} 1$ and T1, microsomal epoxide hydrolase, and cytochrome P450 enzymes as modulators of bladder cancer risk. Cancer Res 56:3915-3925

101. Marcus PM, et al (2000) Cigarette smoking, N-acetyltransferase 2 acetylation status, and bladder cancer risk: a case-series meta-analysis of a gene-environment interaction. Cancer Epidemiol Biomarkers Prev 9:461-467

102. Spurr NK, Gough AC, Chinegwundoh FI, Smith CA (1995) Polymorphisms in drug-metabolizing enzymes as modifiers of cancer risk. Clin Chem 41:1864-1869 